\title{
Do the Type and Number of Blockholders Influence R\&D Investments? New evidence from Spain
}

\author{
Josep A. Tribo*, Pascual Berrone and Jordi Surroca
}

Using data from 3,638 Spanish firms between 1996 and 2000, this article studies the relationship between the presence of large shareholders in the ownership structure of firms and R\&D investment. Consistent with our theoretical contention, our results indicate that the impact of large shareholders on the R\&D investment is (1) negative when blockholders are banks, (2) positive when blockholders are non-financial corporations and (3) null when blockholders are individuals. In addition, we find a systematic negative relationship between the number of blockholders and R\&D investment. Finally, we extend our study by analysing the influence that the combined effect between blockholder type and R\&D investment has on the firm's economic performance. Results of this work provide relevant implications for policy makers and academic research.

Keywords: Ownership structure, banks, institutional blockholders, non-financial blockholders, individual blockholders, R\&D investment

\section{Introduction}

$\mathrm{T}$ he ownership structure of firms is recognised as an important determinant of its general investment policy and, in particular, of its research and development (R\&D) spending (Lee and O'Neil, 2003; Porter, 1990). However, there is no consensus regarding the effect of ownership concentration on a firm's $R \& D$ investment. To date, literature surrounding this relationship has only provided mixed results. While some studies showed a positive relationship between large shareholders and R\&D investment (Hosono et al., 2004; Wahal and McConnell, 2000), others found negative (Yafeh and Yosha, 2003; Jones and Danbolt, 2003) or neutral associations (Francis and Smith, 1995; Holderness and Sheehan, 1988). In addition, previous studies have examined this relationship in Anglo-American contexts (Hoskisson et al., 2002; Porter, 1992, Tylecote and Ramirez, 2006), and more recently some comparative work with Japanese firms has been conducted (Lee, 2005; Lee and O'Neil 2003), but very little is known about these relationships in continental Europe. ${ }^{1}$

The aim of this paper is to reconcile these conflicting results by enriching the analysis of the firm's ownership structure using the Spanish case. The Spanish corporate system has several institutional characteristics that make it suitable in explaining the influence of blockholders on R\&D investments and distinguishes it from those considered in previous research. We move a step further from the simple characterisation of the stake of the main blockholders as the main determinant of a firm's investment policy to incorporate two features: (1) the type of blockholders and (2) the number of blockholders necessary to control a firm. Previous research rested on the assumption that shareholders have homogenous preferences for R\&D strategies. Only recently has the type of blockholder received some attention (e.g. Kochhar and David, 1996;

Lee, 2005; Hoskisson et al., 2002). Extending
Universidad Carlos III, Departamento de Economía de la Empresa, Madrid, 126, 28 Getafe (Madrid), Spain. Tel: 34-916249321/34-916249607; E-mail: joatribo@emp.uc3m.es 
this line of research, we explore three different types of blockholders: banks, non-financial corporations and individuals. By introducing the type of blockholder as explicative element, we can evaluate how differences in preferences may influence firms' R\&D investment. Moreover, we consider the number of blockholders, a variable that has been largely neglected in previous studies, as an additional determinant of corporate innovation strategies.

Using a comprehensive database, we collected data during the period 1996-2000 on 3,638 Spanish companies to test our contention. We found that banks, which are more conservative investors and characterised by debt holdings in firms, influence negatively R\&D expenses, while non-financial blockholders are more willing to promote innovative endeavours as there might be beneficial synergies for them. Concerning individual blockholders, we observed a neutral impact on $R \& D$ investments, since two countervailing effects are at work. On the one hand, individual blockholders are likely to exhibit stringent monitoring and prevent opportunistic actions since their stake represents a significant part of their wealth, and thus are more likely to engage in complex R\&D activities. On the other hand, the wide heterogeneity among individual blockholders may hinder agreements on R\&D decisions, affecting innovative initiatives. Furthermore, we found that as the number of blockholder increases, a disagreement effect hinders concurrence among blockholders which negatively affects $R \& D$ initiatives. Finally, we suggest that R\&D investment in the presence of corporate ownership has a larger effect on performance than when banks or individuals are the blockholders.

\section{Institutional characteristics of the Spanish corporate governance system}

Previous studies using Spanish R\&D data have mainly focused on the effect of internal factors on a firm's innovative behaviour (e.g. Galende and de la Fuente, 2003; Galende and SuarezGonzalez, 1999), but the impact of the ownership structure on $R \& D$ activities has been largely ignored. To the best of our knowledge, there are two exceptions. One is the work by Ortega-Argiles et al. (2005), who considered ownership concentration and the rate of owners in management positions when analysing firms' innovation activities. The other exception is the work by Beneito (2003), who controlled for the presence of a unique owner in her model of R\&D expenditures. Neither of these studies, however, considered the presence of different types of large shareholders and the number of blockholders as we do in our study.

The Spanish context is particularly well suited for our study for two reasons. First, given that our goal is to investigate the distinct effects on R\&D of different types of blockholders, we needed a context where large blockholders were not only present but also influential in the strategic decision process of firms. These large blockholders may be institutional blockholders - defined as those large entity investors from non-financial institutions (corporations) to financial institutions, such as a banks, insurance funds, retirement funds, mutual funds - or non-institutional, like individuals. Spanish firms are characterised by the presence of different types of blockholders (banks, corporations and individual blockholders), which play a prominent role in the firms' ownership structure (Crespi-Cladera and Garcia-Cestona, 2002) and, consequently, participate actively in firms' decisions. Second, the Spanish case may enrich the debate on corporate governance and $R \& D$ issues, which mainly focuses on the dichotomy between insider-dominated and outsider-dominated systems (Lee, 2005). It is often contended (see for example, Becht and Mayer, 2002) that the outsider system corresponds to firms in the US and UK, where ownership is dispersed amongst a large number of outside investors (Leech and Manjon, 2002; Miozzo and Dewick, 2002; Tylecote and Ramirez, 2006), and when institutional blockholders appear they tend to be pension and mutual funds (Aguilera, 2004; AQR, 2005). In contrast, Continental Europe and East Asian countries are related to the insider systems, where firms have high levels of ownership concentration, even when they are listed on stock markets. The Spanish corporate governance system situates in an intermediate position between insider- and outsider-dominated systems (Aguilera, 2004; AQR, 2005), and thus sheds new light on this debate.

Three institutional characteristics of the Spanish corporate governance system support the foregoing statements and account for the presence of different types of blockholders and their relevance in explaining R\&D investments: First, capital markets are considered somewhat underdeveloped in Spain. For instance, the stock market capitalisation as a percentage of GDP in 1997 for Spain was 54.6, significantly lower than for the US (144) or the UK (155), but it is superior to Germany (39) and France (49) (Megginson, 2000). Yet, the number of listed companies is small and accounts for only 0.5 per cent of companies. 
Table 1: Characteristics of corporate governance systems

\begin{tabular}{|c|c|c|c|}
\hline & $\begin{array}{l}\text { Insider-dominated } \\
\text { (Germany and Japan) }\end{array}$ & $\begin{array}{l}\text { Outsider-dominated } \\
\text { (US and UK) }\end{array}$ & Spain \\
\hline Type of control & Insider shareholders & Capital markets & $\begin{array}{l}\text { Insider shareholders } \\
\text { Growing importance } \\
\text { of capital markets }\end{array}$ \\
\hline Ownership of debt and equity & Concentrated & Dispersed & Concentrated \\
\hline Investor orientation & Control-orientated & Portfolio-orientated & Control-orientated \\
\hline Dominant agency conflict & $\begin{array}{l}\text { Controlling vs minority } \\
\text { shareholders }\end{array}$ & $\begin{array}{c}\text { Shareholders vs } \\
\text { management }\end{array}$ & Mixed \\
\hline Role of hostile take-overs & Very limited & Important & Very limited \\
\hline Role of board of directors & $\begin{array}{l}\text { Distinction between managing } \\
\text { and supervisory functions }\end{array}$ & $\begin{array}{l}\text { Competent control } \\
\text { mechanism }\end{array}$ & $\begin{array}{c}\text { Board members manage } \\
\text { the company and also } \\
\text { supervise its activity }\end{array}$ \\
\hline Legal origin & German origin & English origin & French origin \\
\hline Shareholder protection & $\begin{array}{l}\text { Medium (Japan) } \\
\text { Low (Germany) }\end{array}$ & High & Low \\
\hline Creditor protection & $\begin{array}{l}\text { Medium (Germany) } \\
\text { Low (Japan) }\end{array}$ & Low & Low \\
\hline
\end{tabular}

Source: Barca and Becht (2002), and own elaboration.

This explains the emergence of institutional blockholders, especially banks and other financial institutions, as alternative control mechanism. In most Spanish firms, certain capital-intensive decisions like R\&D rely mainly on the controlling blockholder rather than on the presence of financial markets. This facilitates the identification of differential effects on R\&D investments related to the presence of different blockholders.

The second characteristic of the Spanish corporate governance system is the low investors' protection in comparison with US, UK, Japan and Germany (La Porta et al., 1998). This weak investor protection has consequences in terms of expropriation as the level of expropriation is greater when the legal protection of shareholders and creditors is low (La Porta et al., 1999). Thus, the inadequate investor protection explains the existence of large concentrated ownership structures.

Last, the Spanish corporate system is characterised by much more concentrated ownership structure than in Anglo-Saxon countries, but it is lower than several European countries. For instance, Barca and Becht (2002) showed that average Spanish stockholding was 15 per cent for domestic firms, 11 per cent for individuals (including families), and almost 7 per cent for banks versus the holdings in UK, which were 5 per cent, 1.6 per cent and 1.8 per cent, respectively. This superior concentration makes investors more likely to participate actively in firms' decisions
(AQR, 2005), which favours the contrast of differential effects of blockholders on $R \& D$ investments.

Table 1 summarises other characteristics of the Spanish corporate system. Its intermediate position confers particular interest in the conclusions derived from our study, given the expected convergence between insiderdominated and outsider-dominated systems (Rajan and Zingales, 2003).

\section{Theoretical framework and hypotheses}

The separation of ownership and control in modern corporations jointly with the existence of information asymmetries within the firm, spawn the possibility of opportunistic actions by the risk-averse agent - the manager - who may have different objectives from a risk neutral principal - the owner - and thus pursue self-serving priorities, giving birth to the so-called agency problems (Jensen and Meckling, 1976). Three main traits make these problems particularly severe in R\&D investment decisions (Baysinger et al., 1991; Lee, 2005; Tihanyi et al., 2003). First, even though a firm's capability to innovate is expected to generate greater profits (Hirschey, 1985; Jose et al., 1986), R\&D activities are inherently risky as they provide greater variability of outcomes and greater probability of failure despite the best effort of managers (Baysinger et al., 1991). 
Second, R\&D activities require long-term investments that may have a negative impact on more immediate performance (Hoskisson et al., 1993). This is particularly troublesome for liquidity-constrained firms (Devereux and Schiantarelli, 1990; Schaller, 1993), or firms with information asymmetries (Devereux and Schiantarelli, 1990). Consequently, risk-averse managers may be reluctant to invest in risky R\&D projects. Third, R\&D activities generally require high managerial autonomy (Hambrick and Finkelstein, 1987) to be effective, since managers face a wide range of complex strategic choices. But, at the same time, risk-averse managers with great level of discretion may use their power to pursue low-risk strategies, avoiding R\&D initiatives and damaging firms' innovation output (Billings et al., 2004). Thus, the information asymmetry derived from the complexity of innovative endeavours combined with the large managerial discretion needed to guide these projects may be used by risk-averse managers to pursue their selfserving agenda at the expense of the shareholders (agency costs). Agency theory predicts that proper governance mechanisms, like ownership concentration, can reduce agency costs and help to ensure an appropriate level of $R \& D$ investment since they curtail managers' propensity to pursue inefficient strategies (Demsetz and Lehn, 1985; Jensen and Meckling, 1976). However, previous empirical studies offer contradictory results, preventing definitive conclusions. Our position, as argued next, is that these equivocal results can be explained by incorporating two features of blockholders: the type and number of blockholders.

\section{The type of blockholder}

Previous literature portrays conflicting results regarding the link between large shareholders and innovation expenditures. Some studies (e.g. Wahal and McConnell, 2000; Hill and Snell, 1988; Baysinger et al., 1991) found the existence of a positive relationship between the presence of institutional shareholders and R\&D investment. Conversely, Graves (1988) found in a sample of computer firms that the presence of institutional blockholders damaged R\&D investment. Moreover, Chung et al. (2003) deduced that there is no effect on $R \& D$ investment due to the existence of institutional holdings. Also, Francis and Smith (1995) did not find significant differences in R\&D-to-sales ratio when comparing management-controlled firms with externallycontrolled ones (with large and external blockholders). ${ }^{2}$
A common characteristic of all these studies is that they assumed that ownership constituencies have identical preferences for corporate strategies. Only recently, some studies have acknowledged the implications that the identity of such stakeholders can have for firms. Hoskisson et al. (2002) found significant differences between two types of institutional owners (i.e. pension funds and professional investment funds) and firm's innovation strategies. Similarly, we argue that each type of institutional blockholder has a distinguishable impact on the firm's R\&D strategy. Unlike their work, however, we focus on three types of blockholders which have recognised particularities and deserve attention, namely banks, non-financial corporations and individual blockholders.

Because $R \& D$ initiatives require large investments, it is vital to analyse the role of banks as they are often the main sources of financial capital. This is particularly the case for Spanish firms, which face a strong (and sometimes intrusive) bank system and a relatively small stock market (Aguilera, 2004). Spanish firms are also characterised by significant cross-shareholding and directorinterlocks between companies (Aguilera, 2004; AQR, 2005). Thus, the presence of non-financial companies in the ownership structures of firms deserves attention when studying a pivotal decision for a firm's growth like R\&D investments. Finally, as is often the case in continental Europe, wealthy individuals, who generally belong to the same family, own significant portions of companies (Leech and Manjon, 2002). Because a large part of their wealth is at stake in an undiversified investment, individual blockholders have distinct preferences and incentives which can influence the innovation strategy of firms.

Previous empirical evidence suggests that ownership by banks might be related to $R \& D$ initiatives, but results are not conclusive. For instance, while Kochhar and David (1996) found that banks had no significant impact on R\&D outputs, Lee (2005) found a positive and significant relationship. Gugler (2003) also showed that bank-controlled firms exhibit low pay out ratios, which are inversely related to R\&D investments. Contrary to these results, we expect bank blockholders to have a negative impact on R\&D investment for several reasons. First, banks maintain business relationships with the firm in which they invest beyond simple ownership, often in the form of loans and credits (Kroszner and Strahan, 2001). This exposes banks, which are conservative institutions, to the uncertainty of $R \& D$ investment returns through two channels: credits and stakes. Second, the presence of 
banks stimulates firms to raise capital through debt financing (Petersen and Rajan, 1994). The larger the amount of debt, the larger the riskiness of this debt and the more important the distortions that this debt generates in a firm's investment decisions. One of this distortions described in the literature is the short-term investment bias (Grinblatt and Titman, 1998). A firm tends to invest in short-term projects as a way to reduce the burden of its debt. This bias should hinder R\&D investments, which are mainly long-term oriented (Hoskisson et al., 1993). Thus, we expect that when banks are present in the ownership structure of firms, their R\&D related investments would tend to be flattened.

Hypothesis 1: There is a negative influence of a bank's ownership on firm's RED investment intensity.

The second type of institutional blockholder that we identify is the non-financial corporation. We expect a positive influence of the presence of this blockholder on R\&D investment for different reasons:

First, compared to banks, non-financial corporations rarely have credit relationships with their controlled firms (Kroszner and Strahan, 2001; La Porta et al., 2003). This eliminates one channel of uncertainty in R\&D investments for former corporations. Also, the non-existence of these credit relationships reduces debt riskiness and prevents investment inefficiencies like the aforementioned short-term investment bias which, in turn, would favour R\&D investments.

Second, non-financial corporations, unlike banks, are more likely to recognise the relevance of $R \& D$ investment as a pivotal input for their market success. The existence of reciprocal business relationships, potential synergies and spillover effects between the owner and the controlled firms should favour R\&D investment of the latter (Jaffe, 1986). By investing in R\&D, controlled firms can improve their absorptive capacity (Cohen and Levinthal, 1990), enhancing their ability to learn from the corresponding $R \& D$ investments of the owner firms.

Last, in some occasions, owner companies invest in R\&D-intensive firms strategically with the intention of delegating to these firms, that are specialist in such activities, part of their R\&D investments. This allows efficient investments and superior returns. This kind of behaviour is observed in the venture capital industry, where large corporations invest in start-up firms and give these firms incentives for investing in R\&D-intensive projects. If these start-up firms become successful, corporations integrate them in their own division as a way of improving their own R\&D investments (Gompers and Lerner, 2006). Thus,

Hypothesis 2: There is a positive influence of non-financial corporation's ownership on firm's $R E D$ investment intensity.

The last type of blockholder that we identify is the individual or non-institutional blockholder. For this type of blockholder, we expect an ambiguous relationship between its presence and the R\&D investment intensity of the controlled firm due to the existence of two countervailing effects. Baysinger et al. (1991) argued that the absence of a systematic relationship between ownership concentration among individual shareholders and $R \& D$ investment is due to the heterogeneity of individual investors in terms of risk preference and investment horizons. This heterogeneity of individuals is translated into two opposite effects.

On the one hand, monitoring is enhanced when individual blockholders are present because a set of different types of blockholders with different points of view enriches vigilance. At the same time, individual blockholders' stakes represent a significant part of their wealth and thus have an incentive to better observe managers' actions. This enhanced monitoring is expected to favour the investment in complex R\&D activities. On the other hand, agreements on long-term R\&Dintensive projects are more difficult to achieve when there is great heterogeneity among blockholders (disagreement effect). That is, conflicting voices are likely to be present when there is risk and investment horizons heterogeneity among owners (Hoskisson et al., 2002). Thus,

Hypothesis 3: There is an ambiguous impact of individual ownership on firm's RED investment intensity.

\section{Number of blockholders}

We focus on an additional dimension of ownership structure: the number of blockholders that form a coalition to control the firm (control group with a stake larger than 50 per cent). We argue that ceteris paribus, increases in the number of blockholders within control group have an impact on $R \& D$ investment policy. This is so because the existence of a set of large shareholders with different individual objectives makes more difficult to reach consensus on firm decisions, especially in those decisions that involve long-term agreements like those to undertake R\&D-intensive projects. This is the aforementioned disagreement effect. 
Moreover, the existence of a large number of blockholders weakens the degree of monitoring of manager's actions since vigilant responsibilities are diluted among a greater number of dominant shareholders. This, in turn, enhances managerial discretion and consequently managers have greater leeway to pursue low-risk strategies and show selfserving behaviour (Finkelstein and Boyd, 1998; Tosi et al., 1997), evading risky R\&D projects. Thus, we hypothesise the existence of a negative relationship between the number of blockholders and firm R\&D investment policy.

Hypothesis 4: The number of blockholders has a negative influence on firm's RED investment intensity.

\section{The impact of the combined effect between blockholder type and RED expenditures on firm performance}

The ultimate reason for investing in $R \& D$ is to improve the firm's performance. Consequently, a reasonable extension is to analyse whether ownership structure is exclusively a determinant of R\&D or it also plays an additional moderating role connecting R\&D investments and performance. Le et al. (2006) recognised the importance of the presence of different institutional investors like pension funds in moderating positively the impact of $R \& D$ investments on performance.

We content that the impact of R\&D expenditures on performance is contingent to the type of blockholder. We rely on the very basic argument that those blockholders that are keener to stimulate $R \& D$ investment will have more incentives to extract superior returns from these investments in comparison with others less interested in these investments. Specifically, given the above considerations concerning different types of blockholders, we expect corporate owners to be more efficient in channelling $\mathrm{R} \& \mathrm{D}$ investment into productive outcomes. They have more experience in taking part of different $R \& D$ projects, either in the same firm or in other companies. This improves the skills of corporate owners (learning-by-doing) in managing R\&D-intensive projects which should translate into superior returns from these investments. Unsurprisingly, these corporate blockholders often decide to participate in certain firms with the intention to develop part of their R\&D activities in such firms because they are more flexible and efficient. Moreover, this outsourcing puts pressure on the own division of the corporate blockholder for increasing their returns from $R \& D$ investments; otherwise, there will be more delegation in favour of the partially-owned firm. This logic explains the corporate venture capital phenomenon (Gompers and Lerner, 2006). Thus,

Hypothesis 5: There is a larger marginal impact of RED investments on performance when corporations are blockholders compared with other types of blockholders like banks or individuals.

\section{Methods}

\section{Sample and data}

We use the SABE databases for the years 19962000, which are available from Bureau Van Dijk and provide the ownership structure, balance sheets and income statements for over 190,000 Spanish firms (95 per cent of all Spanish companies) that deposit their financial statements in the Central Mercantile Register (Registro Mercantil Central). We restrict the sample using three criteria: we eliminate firms that do not report the ownership structure, those that do not present detailed financial statements and those that are not corporations (cooperatives, partnerships and proprietorship). Moreover, these three criteria have to be satisfied for at least three of the five available years. The final sample is an unbalance panel of 3,638 different firms and 12,685 firm-year observations.

\section{Measures}

\section{Dependent variables}

$R \mathcal{E D}$ intensity. The variable to characterise a firm's R\&D policy is its $R \mathcal{E} D$ intensity that is defined in terms of the ratio of $R \& D$ expenditures to total sales.

Financial performance. We approach firm performance through the Return on Assets (ROA) defined as the ratio of earnings before interests and taxes to the total value of assets. For the sake of robustness, we also provide results using the return on equity measure defined as the ratio of profits to the equity book value.

\section{Independent variables}

Variables of ownership structure. The first dimension of the ownership structure is the type of blockholder. We distinguish between banks, non-financial corporations and individuals. We define as Bank ownership the stake in the hands of banks; Corporate ownership the stake in the hands of other firms; and Individual ownership the stake in the hands of individuals (non-institutional blockholders). Two comments are in order. First, we consider different thresholds in the stake to define a block- 
holder, ranging from 0 per cent to 20 per cent (in the tables we show the results of the extreme cases of no threshold and 20 per cent threshold). ${ }^{3}$ Second, we follow Bennedsen and Wolfenzon (2000) to define the number of blockholders that form the controlling coalition (Number controlling blockholders). When the largest shareholder owns more than 50 per cent of the shares, we assume that it is the only member of the coalition. When the largest shareholder owns less than 50 per cent, for a given ownership structure many different controlling coalitions may be formed. In a rough simplification, we assume that in this case the two largest shareholders will always be in the coalition. If the joint stake of the two largest shareholders is lower than 50 per cent, then the coalition will also include the third largest shareholder and so on.

To study crossed effects between the aforementioned dimensions, we consider variables Bank ownership $\times$ Number that is the product of Bank ownership times the Number controlling blockholders. Following the same logic, we define Corporate ownership $\times$ Number and Individual ownership $\times$ Number.

In the performance specifications, we identify those firms with a value of R\&D intensity larger than the mean for the sector in the corresponding year with a dummy variable Dummy RED. Also, we consider the interactive effect of the ownership structure and $\mathrm{R} \& \mathrm{D}$ investment on a firm performance. This leads to define the following variables Bank ownership $\times$ Dummy RED that is the product of Bank ownership times the Dummy RED variable. Following the same logic, we define Corporate ownership $\times$ Dummy RED, Individual ownership $\times$ Dummy RED and Number controlling blockholders $\times$ Dummy $R \mathcal{E} D$.

\section{Control variables}

We control for size effects with the Sales variable that is the amount of sales on a log scale. We also control for the financial structure, which is captured with two variables (Galende and Suarez-Gonzalez, 1999). First, Debt-toequity, which is the ratio of book value of debt to the book value of equity. Second, Internal funds-to-assets, which is the ratio of a firm's internal funds to the overall value of a firm's assets. We control for performance through the ROA variable (we lagged this variable one period and named it $R O A\{t-1\}$ to prevent potential endogeneity problems). Also, in order to capture the existence of some inertia in $R \& D$ investment decisions, which are mainly long-term, we include the dependent variable of $R \& D$ intensity lagged by one period $R \mathcal{E} D\{t-1\}$. Additionally, we introduce as control a variable family that is a dummy that is equal to 1 when there are blockholders that belong to the same family. Finally, we controlled for sector and year by detracting from the dependent variables its mean value by year and 1-digit sector in the fixed-effect estimation. ${ }^{4}$ For non fixed-effect estimations, we introduce temporal and sectoral dummies. ${ }^{5}$

\section{Data analysis and model specification}

Our main specification is aimed to test the effect of different types of blockholders as well as its number on a firm's R\&D investment intensity. We focus on the following specification:

$$
\begin{aligned}
& R \& D \text { intensity }_{i t}= \\
& \alpha+\beta_{1}\left(\text { Bank ownership }_{i t}\right) \\
& \left.+\beta_{2} \text { (Corporate ownership }{ }_{i t}\right) \\
& \left.+\beta_{3} \text { (Individual ownership } p_{i t}\right) \\
& \left.+\beta_{4} \text { (Bank ownership } \times \text { Number }_{i t}\right) \\
& +\beta_{5}\left(\text { Corporate ownership } \times \text { Number }_{i t}\right) \\
& \left.+\beta_{6} \text { (Individual ownership } \times \text { Number }_{i t}\right) \\
& \left.+\beta_{7} \text { (Number controlling blockholders }_{i t}\right) \\
& +\beta_{8}\left(\text { Family }_{i t}\right)+\beta_{9}\left(R O A_{i t-1}\right) \\
& \left.+\beta_{10}\left(R \& D \text { intensity }_{i t-1}\right)+\beta_{11} \text { (Sales }_{i t}\right) \\
& +\beta_{12}\left(\text { Debt-to-equity }{ }_{i t}\right) \\
& +\beta_{13}\left(\text { Internal funds-to-assets } s_{i t}\right)+u_{i}+\varepsilon_{i t}
\end{aligned}
$$

To test the effects on performance of different combinations of blockholders and a firm's R\&D investment, we used the following specification:

$$
\begin{aligned}
& R O A_{i t}= \\
& \left.\alpha+\beta_{1} \text { (Bank ownership }{ }_{i t}\right) \\
& \left.+\beta_{2} \text { (Corporate ownership }_{i t}\right) \\
& \left.+\beta_{3} \text { (Individual ownership } p_{i t}\right) \\
& +\beta_{4}\left(\text { Number controlling blockholders }_{i t}\right) \\
& +\beta_{5}\left(\text { Bank ownership } \times \text { Dummy } R \& D_{i t}\right) \\
& +\beta_{6}\left(\text { Corporate ownership } \times \text { Dummy } R \& D_{i t}\right) \\
& \left.+\beta_{7} \text { (Individual ownership } \times \text { Dummy } R \& D_{i t}\right) \\
& +\beta_{8} \text { (Number controlling blockholders } \\
& \left.\times \text { Dummy } R \& D_{i t}\right)+\beta_{9}\left(\text { Dummy } R \& D_{i t}\right) \\
& +\beta_{10}\left(\text { Family }_{i t}\right)+\beta_{11}\left(\text { Sales }_{i t}\right) \\
& \left.+\beta_{12} \text { (Debt-to-equity }{ }_{i t}\right) \\
& +\beta_{13}\left(\text { Internal funds-to-assets }{ }_{i t}\right)+u_{i}^{\prime}+\varepsilon_{i t}^{\prime}
\end{aligned}
$$

In both estimations, we recognise the possible existence of unobservable heterogeneity $u_{i}, u_{i}^{\prime}$ potentially correlated with a firm's ownership structure and/or other independent variables. We consider that there may be some unobservable firm characteristics, like managerial skills, that may affect R\&D policy and/or firm's performance and the same characteristics also may attract a particular type of 
blockholder. This may generate a correlation between a firm's intrinsic and unobservable characteristics $u_{i}, u_{i}^{\prime}$ and its type of blockholder. We deal with this problem by making use of fixed-effect techniques (within group estimators). ${ }^{6}$

\section{Results}

Table 2 describes the main variables used in our hypotheses testing. The average stake of the largest blockholder is 68.97 per cent, indicating the large ownership concentration in Spanish firms. Also, the stake in the hands of banks is, on average, 30.79 per cent; 77.47 per cent for other corporations and 67.14 per cent for individuals. ${ }^{7}$ The number of blockholders in the controlling coalition is significantly lower for those firms that invest significantly in $R \& D$ (dummy $R \& D=1$ ) in comparison with those that do not, suggesting initial support for Hypothesis 4. Finally, those firms that invest intensively on R\&D are more profitable, larger and with family participation.

Table 3 shows the results of the presence of different types of blockholders on a firm's R\&D intensity. For robustness, in column 4, we imposed a minimum threshold stake of 20 per cent to define a blockholder. In the last column, as an extension, we incorporated a new variable (Large $\times$ individual ownership) that is the product of a dummy (Large), which is equal to 1 when an individual stake is larger than 50 per cent, times individual blockholder's stake. This allows us to study the expected null effect that individual stake on R\&D holds independently of whether that stake is large or small.
When focused on the type of blockholder, we find that banks' ownership has a significant negative impact on R\&D investment; the presence of corporate blockholders stimulates this kind of investments, while noninstitutional blockholders (individuals) do not have a significant impact. These results conform to Hypotheses 1, 2 and 3, respectively.

Concerning the number of blockholders, all specifications, except one, show a negative impact on a firm's R\&D intensity. These results are consistent with those obtained by OrtegaArgiles et al. (2005). Overall, results suggest that a disagreement effect exists and it hinders R\&D investments as predicted by Hypothesis 4. However, when considering a minimum stake of 20 per cent (column 4), this variable is not significant. A plausible explanation for this result is that with the 20 per cent threshold there are only a few blockholders because the condition to be a blockholder is more demanding. And, a larger number of blockholders is needed to capture the negative impact (disagreement effect) on $R \& D$ investment.

The interaction between the types of blockholders and their number reveals that the existence of a large number of blockholders has a negative moderating effect when other corporations have a controlling role in a firm. Also, for individual blockholders, this moderating effect of increases in the number of blockholders is neutral regardless whether the stake of individual blockholders is larger (Large $=1$ ) or lower than 50 per cent $($ Large $=0)$.

Consistent with the findings by Galende and Suarez-Gonzalez (1999), who used identi-

Table 2: Means and standard deviations ${ }^{\mathrm{a}}$

\begin{tabular}{lccccc}
\hline & Mean & St. Dev. & R\&D $=1^{\mathrm{a}}$ & R\&D $=0^{\mathrm{a}}$ & T-test (p-value) \\
\hline R\&D intensity & 0.006 & 0.058 & 0.046 & 0.001 & $0.000^{* * * *}$ \\
ROA & 0.090 & 0.189 & 0.102 & 0.088 & $0.008^{* * *}$ \\
Bank ownership & $30.787 \%$ & $33.559 \%$ & $27.062 \%$ & $31.657 \%$ & 0.261 \\
Corporate ownership & $77.469 \%$ & $29.741 \%$ & $74.653 \%$ & $81.403 \%$ & $0.000^{* * * *}$ \\
Individual ownership & $67.143 \%$ & $37.868 \%$ & $72.516 \%$ & $57.523 \%$ & $0.000^{* * *}$ \\
Stake of the largest & $68.969 \%$ & $31.359 \%$ & $69.945 \%$ & $68.839 \%$ & 0.199 \\
$\quad$ blockholder & 1.279 & 0.723 & 1.229 & 1.285 & $0.004^{* * *}$ \\
Number controlling & & & & & \\
$\quad$ blockholders & 14.774 & 1.391 & 14.871 & 14.761 & $0.004^{* * * *}$ \\
Sales & 6.979 & 549.091 & 1.364 & 7.686 & 0.686 \\
Debt-to-equity & 0.377 & 0.317 & 0.364 & 0.379 & $0.077^{*}$ \\
Internal funds-to-assets & 0.148 & 0.356 & 0.068 & 0.150 & $0.000^{* * * *}$ \\
Family & & & & & \\
\hline
\end{tabular}

${ }^{a}$ We define $R \& D=1(0)$, when $R \& D$ intensity is larger or equal (lower) than the mean for the sector (1-digit) and year.

${ }^{*} p \leq 0.10 ;{ }^{* *} p \leq 0.05 ;{ }^{* * *} p \leq 0.01$. 
Table 3: Determinants of RED investment intensity: full sample

The dependent variable is the R\&D intensity corrected by sector and year. In columns 1, 2, 3, 5, it is not imposed a minimum threshold to define what a blockholder is, while in column 4 the threshold is $20 \%$.

(1)

\begin{tabular}{|c|c|c|c|c|c|}
\hline Dependent variable & R\&D/sales & R\&D/sales & R\&D/sales & R\&D/sales & R\&D/sales \\
\hline Bank ownership & & $\begin{array}{l}-0.0586^{* * *} \\
(-4.8100)\end{array}$ & $\begin{array}{l}-0.0710^{* * *} \\
(-4.6500)\end{array}$ & $\begin{array}{l}-0.0716^{* * *} \\
(-2.5800)\end{array}$ & $\begin{array}{l}-0.0712^{* * * *} \\
(-4.66)\end{array}$ \\
\hline Corporate ownership & & $\begin{array}{l}0.0225^{* * *} \\
(2.9900)\end{array}$ & $\begin{array}{l}0.0786^{* * *} \\
(4.5400)\end{array}$ & $\begin{array}{l}0.1298^{* * *} \\
(3.8000)\end{array}$ & $\begin{array}{l}0.0859^{* * *} \\
(4.67)\end{array}$ \\
\hline Individual ownership & & $\begin{array}{c}0.0155 \\
(1.0500)\end{array}$ & $\begin{array}{l}-0.0156 \\
(-0.3900)\end{array}$ & $\begin{array}{l}-0.0089 \\
(-0.1400)\end{array}$ & $\begin{array}{l}-0.1304 \\
(-0.84)\end{array}$ \\
\hline Large $\times$ Individual ownership & & & & & $\begin{array}{l}0.1528 \\
(0.95)\end{array}$ \\
\hline Bank ownership $\times$ Number & & & $\begin{array}{c}0.0135 \\
(1.2900)\end{array}$ & $\begin{array}{c}0.0171 \\
(0.7000)\end{array}$ & $\begin{array}{l}0.0139 \\
(1.33)\end{array}$ \\
\hline Corporate ownership $\times$ Number & & & $\begin{array}{l}-0.0587^{* * *} \\
(-3.5800)\end{array}$ & $\begin{array}{l}-0.1047^{* * *} \\
(-3.1600)\end{array}$ & $\begin{array}{l}-0.0665^{\text {*** }} \\
(-3.78)\end{array}$ \\
\hline Individual ownership $\times$ Number & & & $\begin{array}{c}0.0350 \\
(0.9900)\end{array}$ & $\begin{array}{c}0.0290 \\
(0.4700)\end{array}$ & $\begin{array}{l}0.1058 \\
(1.31)\end{array}$ \\
\hline Large $x$ Individual ownership $\times$ Number & & & & & $\begin{array}{l}-0.1094 \\
(-1.22)\end{array}$ \\
\hline Number controlling blockholders & & $\begin{array}{l}-0.0216^{* * *} \\
(-2.6700)\end{array}$ & $\begin{array}{l}-0.0238^{* * *} \\
(-2.6300)\end{array}$ & $\begin{array}{c}-0.0008 \\
(-0.0900)\end{array}$ & $\begin{array}{l}-0.0245^{* * *} \\
(-2.70)\end{array}$ \\
\hline Family & $\begin{array}{l}-0.0052 \\
(-0.6700)\end{array}$ & $\begin{array}{c}0.0018 \\
(0.2500)\end{array}$ & $\begin{array}{c}0.0093 \\
(1.2500)\end{array}$ & $\begin{array}{c}0.0083 \\
(1.0600)\end{array}$ & $\begin{array}{l}0.0109 \\
(1.37)\end{array}$ \\
\hline$R O A\{t-1\}^{\mathrm{b}}$ & $\begin{array}{c}0.0027 \\
(0.5100)\end{array}$ & $\begin{array}{c}0.0017 \\
(0.3100)\end{array}$ & $\begin{array}{c}0.0009 \\
(0.1600)\end{array}$ & $\begin{array}{c}0.0012 \\
(0.2100)\end{array}$ & $\begin{array}{l}0.0008 \\
(0.15)\end{array}$ \\
\hline$R \mathcal{E} D\{t-1\}^{c}$ & $\begin{array}{l}0.1280^{* * *} \\
(8.6200)\end{array}$ & $\begin{array}{l}0.1152^{* * *} \\
(7.5900)\end{array}$ & $\begin{array}{l}0.1099^{* * *} \\
(7.2200)\end{array}$ & $\begin{array}{l}0.1155^{* * *} \\
(7.6100)\end{array}$ & $\begin{array}{l}0.1098^{* * * *} \\
(7.21)\end{array}$ \\
\hline Sales & $\begin{array}{l}-0.0029 \\
(-0.6800)\end{array}$ & $\begin{array}{l}-0.0025 \\
(-0.6100)\end{array}$ & $\begin{array}{c}-0.0024 \\
(-0.5700)\end{array}$ & $\begin{array}{l}-0.0028 \\
(-0.6700)\end{array}$ & $\begin{array}{l}-0.0024 \\
(-0.58)\end{array}$ \\
\hline Debt-to-equity & $\begin{array}{c}0.0001 \\
(0.0300)\end{array}$ & $\begin{array}{c}0.0001 \\
(0.0200)\end{array}$ & $\begin{array}{c}0.0001 \\
(0.0200)\end{array}$ & $\begin{array}{c}0.0001 \\
(0.0200)\end{array}$ & $\begin{array}{c}0.0001 \\
(0.02)\end{array}$ \\
\hline Internal funds-to-assets & $\begin{array}{c}0.0115 \\
(1.2300)\end{array}$ & $\begin{array}{c}0.0117 \\
(1.2300)\end{array}$ & $\begin{array}{c}0.0104 \\
(1.0900)\end{array}$ & $\begin{array}{c}0.0109 \\
(1.1400)\end{array}$ & $\begin{array}{l}0.0105 \\
(1.10)\end{array}$ \\
\hline Intercept & $\begin{array}{c}0.0057 \\
(0.9700)\end{array}$ & $\begin{array}{l}-0.0046 \\
(-1.2800)\end{array}$ & $\begin{array}{l}-0.0035 \\
(-0.9500)\end{array}$ & $\begin{array}{l}-0.0033 \\
(-0.8800)\end{array}$ & $\begin{array}{l}-0.0037 \\
(-1.02)\end{array}$ \\
\hline Hausman Test & $\begin{array}{l}4421.39 \\
(0.0000)\end{array}$ & $\begin{array}{l}4032.49 \\
(0.0000)\end{array}$ & $\begin{array}{l}4049.48 \\
(0.0000)\end{array}$ & $\begin{array}{l}4421.39 \\
(0.0000)\end{array}$ & $\begin{array}{l}4048.92 \\
\quad(0.0000)\end{array}$ \\
\hline Fixed effects & Yes & Yes & Yes & Yes & $\begin{array}{r}\text { Fixed } \\
\text { effects }\end{array}$ \\
\hline Fitness test & $\begin{array}{l}20.97 \\
(0.0000)\end{array}$ & $\begin{array}{l}10.25 \\
(0.0000)\end{array}$ & $\begin{array}{l}9.09 \\
(0.0000)\end{array}$ & $\begin{array}{l}7.98 \\
(0.0000)\end{array}$ & $7.98^{* * *}$ \\
\hline Adjusted $R^{2}$ & $32.27 \%$ & $51.41 \%$ & $46.39 \%$ & $58.70 \%$ & 46.16 \\
\hline Number of observations & 8110 & 8110 & 8110 & 8110 & 8110 \\
\hline
\end{tabular}

(3)

(4)

(5)

aStandardised regression coefficients are shown in the table. ${ }^{*} p \leq 0.10{ }^{* *} p \leq 0.05{ }^{* * *} p \leq 0.01$

${ }^{\mathrm{b}} R O A\{t-1\}$ means $R O A$ lagged by one period. We have lagged this variable to avoid potential endogeneity problems.

${ }^{c} R \mathcal{E} D\{t-1\}$ means R\&D intensity lagged by one period.

cal variables to those of our specification and also applied to Spanish data, we observe that financial structure (debt-to-equity) do not have a significant impact on R\&D investment. However, the literature establishes, in general, a negative impact of leverage on $R \& D$ (Bah and Dumontier, 2001; Carpenter and Petersen, 2002; Chiao, 2002; Hall, 1992). ${ }^{9}$ Unlike our study, these papers do not include a full characterisation of a firm's ownership structure. 
Hence, differences may be explained by the effect of ownership structure that outweighs those of financial structure. To investigate this issue more in-depth, we have decomposed (in an unreported specification available upon request) the variables of financial structure into two variables: the first was the long-term debt to asset ratio and the second was the short-term debt to assets ratio. We found that the null impact of the variable of financial structure is due to the aggregation of two effects. The positive effect on $R \& D$ due to the long-term debt and a non-significant effect connected to short-term debt. Remarkably, these results hold regardless whether we include variables of ownership structure or not. Hence, the length of the financial structure is what is relevant in determining $R \& D$ investment. This is not surprising given that $R \& D$ investments are mainly long-term (Hoskisson et al., 1993) and there should be a positive linkage between the length of the investments and that of the financial instruments (Von Thadden, 1995). Finally, concerning the internal funds, the non-significant result is also consistent with Galende and Suarez-Gonzalez (1999). Other studies found a positive impact. However, the linkage between investment and internal funds is mainly found in liquidityconstrained firms (Devereux and Schiantarelli, 1990; Schaller, 1993) or firms that suffer agency costs (Devereux and Schiantarelli, 1990). ${ }^{10}$ Remarkably, in our sample only 2.57 per cent of the firms suffer liquidity constraints according to a measure developed by Asquith et al. (1994). ${ }^{11}$

Finally, we analyse the moderating effect of ownership structure on the impact of significant R\&D investments on performance (see Table 4). We find that this is positive and significant, but only when non-financial firms are the largest blockholders. This result holds regardless the financial measure used ( $R O A$ or $R O E$ ) and independently of the threshold used to define a blockholder (20 per cent or 0 per cent). This provides robust support to Hypothesis 5. Also, we have found that there no difference in moderating effect of individual ownership stake contingent on their stake once we analyse the connection between $R \& D$ investments and performance. This is consistent with what we have found analysing the determinants of R\&D.

\section{Discussion and conclusion}

Decisions regarding the magnitude and allocation of R\&D expenditures are extremely important for corporations, and it is crucial to identify the configurations that foster innova- tion activities. Thus, this study is important for both investors and public authorities, as it helps identifying idiosyncratic ownership structures that favour R\&D investment.

\section{The type of blockholders}

Large shareholders play a decisive role in critical corporate decisions (Tirole, 2001). These blockholders have the incentives and the power to influence management's discretion with respect to R\&D strategies. However, previous literature has provided ambiguous results concerning ownership concentrations and R\&D investments, and has generally assumed that ownership constituencies have identical preferences for innovation strategies. This article offers an alternative perspective that helps reconciling conflicting results found in the literature.

Consistent with the ownership structure of European firms, we have examined the effect of three blockholders - banks, non-financial corporations and individuals - and found that bank ownership is negatively related with R\&D investments, whereas non-financial corporation ownership shows a positive impact and individual ownership has a neutral effect.

We have drawn on the conservatism of banks in their investment policy and in their potential role as lenders of their partiallyowned firms to justify their negative impact on a firm's R\&D investment. Also, we have argued that banks entail a superior capacity to raise debt which may generate inefficiencies like the short-term investment bias which damage $R \& D$ investments.

We have relied upon the knowledge accumulated through their own R\&D investment track to justify the positive impact of nonfinancial corporations on R\&D investment of controlled firms. Owner firms have incentives to influence managerial decisions towards R\&D projects developed within their controlled firms, as they can take advantage of future spillovers.

The neutral effect of individual ownership that we have found is consistent with the evidence found by Baysinger et al. (1991). This is explained by the characteristics of this group: they have more powerful incentives to scrutinise managerial decisions than institutional blockholders (i.e. banks and corporations) because individual blockholders' stakes represent a significant part of their wealth, but at the same time, the high heterogeneity of these blockholders complicate the agreement on what investments should be made (disagreement effect). This damages a firm's R\&D investments. 
Table 4: Performance analyses by the type of blockholder ${ }^{\mathrm{a}}$

The dependent variable is the Return on assets $(R O A)$ for columns 1, 2 and 3; while it is the return on equity for the other columns. Also, in columns 1, 2, 4, it is not imposed a minimum threshold to define a blockholder, while in columns 3 and 5 , the threshold is $20 \%$.

Dependent variable

Bank ownership

Corporate ownership

Individual ownership

Large $\times$ Individual ownership

Number controlling blockholders

Bank ownership $\times$ Dummy R\&D

Corporate ownership $\times$ Dummy R\&D

Individual ownership $\times$ Dummy R\&D

Large $x$ Individual ownership $\times$ Dummy $R \& D$

Number controlling blockholders $\times$ Dummy R\&D

Dummy R\&D

Family

Sales

Debt-to-equity

Internal funds-to-assets

Intercept

Hausman Test

Fixed effects

Fitness Test

Adjusted $R^{2}$

Number of observations
(1)

(2)

ROA
-0.0024
$(-0.1600)$
$0.0576^{* *}$
$(2.3200)$
$0.0753^{* * *}$
$(3.3400)$

$-0.0160$

$(-1.3800)$

0.0076

(0.7300)

$0.0586^{* * *}$

(3.2600)

0.0060

(0.2900)

$-0.0137$

$(-0.7900)$

$-0.0092$

$(-0.4400)$

$0.0276^{* *}$

(2.2800)

$0.0580^{* * *}$

(7.2300)

0.0009

(0.1600)

$0.4346^{* * *}$

(35.4600)

0.0027

(0.1500)

31.48

(0.2518)

No

1390.46

(0.0000)

$15.00 \%$

12444

ROA

ROA
-0.003

$(-0.170)$

$0.058^{\text {**** }}$

(2.340)

0.021

(0.290)

0.057

(0.790)

$-0.016$

$(-1.350)$

0.008

(0.740)

$0.058^{* * * *}$

(3.200)

0.078

(0.860)

$-0.074$

$(-0.820)$

$-0.014$

$(-0.810)$

$-0.009$

$(-0.440)$

$0.028^{* * * *}$

(2.250)

$0.058^{* * *}$

(7.230)

0.001

(0.160)

$0.435^{\text {*** }}$

(35.470)

0.003

(0.140)

31.49

(0.3425)

No
1391.08

(0.0000)

$15.00 \%$

12444

(3)

(4)

(5)

$\begin{array}{ccc}\text { ROA }(20 \%) & \text { ROE } & \text { ROE }(20 \%) \\ 0.002 & -0.002 & -0.002 \\ (0.120) & (-1.430) & (-1.290) \\ 0.060^{* * *} & 0.002^{* *} & 0.006^{* * *} \\ (2.520) & (1.860) & (2.550) \\ 0.024 & -0.003 & 0.003 \\ (0.260) & (-0.450) & (0.250) \\ 0.054 & 0.001 & -0.003 \\ (0.610) & (0.090) & (-0.260) \\ 0.017 & 0.000 & -0.001 \\ (1.390) & (-0.210) & (-0.750) \\ 0.006 & 0.001 & 0.001 \\ (0.540) & (1.440) & (1.270) \\ 0.063^{* * *} & 0.007^{* * *} & 0.006^{* * *} \\ (3.520) & (3.530) & (3.360) \\ 0.060 & -0.018 & 0.003 \\ (0.600) & (-1.120) & (0.230) \\ -0.056 & 0.020 & -0.000 \\ (-0.550) & (1.270) & (-0.020) \\ -0.023 & -0.001 & 0.000 \\ (-1.030) & (-0.500) & (0.250) \\ 0.000 & -0.003^{* * *} & -0.004^{* * *} \\ (-0.010) & (-2.490) & (-2.640) \\ 0.035^{* * *} & 0.000 & 0.002^{*} \\ (2.850) & (0.140) & (1.78) \\ 0.058^{* * *} & 0.002^{* * *} & 0.001^{* * *} \\ (7.290) & (3.320) & (2.890) \\ 0.001 & -0.232 & -0.232 \\ (0.160) & (-9.280) & (-9.290) \\ 0.434^{* * *} & 0.017^{* * *} & 0.016^{* * *} \\ (35.470) & (11.390) & (11.110) \\ 0.002 & -0.007^{* * *} & -0.007^{* * * *} \\ (0.130) & (-20.500) & (-20.340) \\ 38.02 & 136.70 & 138.19 \\ (0.1219) & (0.0000) & (0.0000) \\ \text { No } & \text { Yes } & \text { Yes } \\ 1455.28 & 12.88 & 11.70 \\ (0.0000) & (0.0000) & (0.0000) \\ 16.30 \% & 3.93 \% & 3.98 \% \\ & 12069 & 12069 \\ & & \end{array}$

aStandardised regression coefficients are shown in the table. The estimations include temporal and sectoral dummy variables when they are not fixed. $p \leq 0.10 ;{ }^{* *} p \leq 0.05 ;{ }^{* * *} p \leq 0.01$.

\section{The number of blockholders}

We have also found empirical support for our expectation of a negative impact of the number of blockholders on a firm's R\&D. A set of large shareholders with different preferences set hurdles in agreements about firm decisions, depressing R\&D investments.

This result is somewhat in line with the notion of managerial discretion (Finkelstein 
and Boyd, 1998). As the stock ownership is more disperse, managerial discretion increases and risk-averse managers would allocate resources away from risky projects. This suggests that investors should invest with caution in firms with a high number of blockholders, especially if the company belongs to a hightech sector, where innovation is vital for organisational survival.

\section{Performance analysis}

The previous discussion raises a natural question: Does the control device of large shareholders lead to appropriate investment decisions? Our results suggested that when firms engage in conspicuous $R \& D$ projects (i.e. $R \& D$ investments higher than the mean of the sector), the presence of non-financial corporations as large shareholders has a positive impact on financial performance. This result is an illustration of the positive influence of corporations, which are expected to have their own experience in managing $R \& D$ investments, in leading their partially-owned firms to choose those projects that improve financial performance.

\section{Policy implications}

In the past decades governments worldwide set out privatisation programmes of stateowned firms. In some cases, like the Czech Republic, the ownership structure of firms that emerged after privatisation was much diluted. Our results indicate that this dilution (an increase in the number of blockholders) may be prejudicial, as it has a negative impact on the R\&D investments. Second, in countries like Spain, the government promoted after the privatisation programme (particularly from 1996 to 2003), the creation of stable investors ("núcleos duros") that were mainly composed of banks. We have shown that this may have a perverse effect in the R\&D policies followed by the recently-privatised firms, which may damage their growth perspectives. Last, governmental agencies that allocate funds to stimulate firms' R\&D investment should take into consideration the relevant role that ownership structure plays in promoting such investments and also in moderating their impact on performance. As a rule of thumb, these agencies should give priority to those firms included by other firms in their ownership structure as significant blockholders.

\section{Future research}

Future research could study the extent to which R\&D investments may be used as a mechanism of earnings management by controlling blockholders. It could be argued that by investing in $R \& D$, firms may channel more easily accounting expenses and smooth income. Given this, an institutional blockholder with a controlling stake in R\&Dintensive firms may stimulate these practices to consolidate this income-smoothing policy in their own balance sheet. A second avenue refers to the analysis of other types of institutional investors (e.g. mutual and pension funds) that are less common in the Spanish context. Also, the use of alternative measures of corporate governance and financial performance (e.g. market-based measures), to which we did not have access, would allow a more finely grained analysis to validate our results. In addition, ownership structure is only one mechanism that may influence R\&D investment, but others like composition of the board or CEO duality may be of interest for future research.

\section{Notes}

1. An exception is the work by Gugler (2003) that uses Austrian data and distinguishes between state-controlled, family-controlled, bank-controlled and foreign-controlled firms. He found that for state-controlled firms the pay-out ratio is larger than for foreign-controlled which in turn are larger than bank-controlled, being the firms with the lowest pay-out ratio family firms. This author connects inversely pay-out ratios to R\&D investments.

2. Other studies look at different aspects of ownership structure, like foreign ownership, and find a positive connection between this latter variable and R\&D investment (Love et al., 1996).

3. Note that the 10 per cent threshold proposed by La Porta et al. (1999) is included in our range. Moreover, the results using a 10 per cent threshold are consistent with those shown in the paper (no threshold or 20 per cent threshold).

4. We use a classification of sectors (CNAE) that has a correspondence with more standard SIC codes (available upon request).

5. We had to rule out sectoral and temporal dummies in the fixed-effect estimation because these variables would have been dropped out.

6. The way to inspect whether there is correlation or not is through the Hausman test that studies whether those coefficients of the fixed-effect estimation are equal to those of the randomeffects estimations. If this null hypothesis is rejected, the only consistent estimator is the fixed-effects one. If not, the best alternative is to use the random-effect estimation. Additionally, in unreported estimations, we allowed for the possibility of a second endogeneity problem not linked to the unobservable heterogeneity, but to the error component. This may perfectly 
be the case as we incorporate in the specification of R\&D intensity the dependent variable lagged by one period as a way to capture the persistence of R\&D investment decisions. We addressed this second endogeneity problem making use of GMM techniques (available upon request). However, results barely change from those provided in Table 3 . Hence, the main source of endogeneity is the unobservable heterogeneity that has been eliminated through fixed-effect estimations.

7. It is remarkable that we obtain a positive impact on R\&D investment only for the presence of corporations, which have, on average, a larger stake. Hence, it seems that the larger the stake of blockholders, the larger the incentives for investing in $R \& D$.

8. It may be the case that blockholders' banks are also lenders (Kroszner and Strahan, 2001) and the negative impact of banks' stake relies on increases in the cost of capital of bank credits. To eliminate such possibility, we have re-estimated the specifications (available upon request) replacing the overall debt by shortterm bank debt. The results show that bank debt has a null effect on R\&D investment while the negative coefficient of "banksown" still holds. That is, when we extract from banks' stake the effect of the lending channel - by including a variable of bank debt - there is still a negative impact of banks' stake on R\&D. We thank an anonymous referee for this comment.

9. One of the seminal papers that captured this relationship in the US was the work by Hall (1992). This relationship was later confirmed by Chiao (2002), who found equivalent results even after separating R\&D investment from physical investment. Bah and Dumontier (2001) obtained similar results using an international database. Finally, Carpenter and Petersen (2002) found that small high-tech firms prefer equity financing than debt financing and, once they are listed on the stock market, internal financing is the best alternative.

10. Consistent with Devereux and Schiantarelli (1990), once we focus on growth firms - whose increase in the sales rate is larger than the mean of the corresponding sector - we have found that the variable of internal funds has a positive effect on R\&D investments, while long-term debt has a negative one. Note that in these firms problems of information asymmetries and liquidity needs are particularly acute.

11. A firm is in financial distress when the interest coverage ratio - defined as the ratio of earnings before interest, taxes and amortisation to the reported interest expenses - falls from a value more than or equal to 2 , to a value less than or equal to 1 in the next period.

\section{References}

Aguilera, R. V. (2004) Corporate governance and employment relations: Spain in the context of western Europe. In A. Pendleton and H. Gospel (eds) Corporate Governance and Labour Management: An International Perspective. Oxford: Oxford University Press.

AQR (2005) Innovación y estructura de propiedad de las empresas españolas. Colección del pensamiento PYME. Colección del pensamiento PYME ed. Madrid: Ministerio de industria, turismo y comercio. Departamento de Econometría, Estadística y Economía Española. Universitat de Barcelona.

Asquith, P., Gertner, R. and Scharfstein, D. (1994) Anatomy of Financial Distress: An Examination of Junk-bond Issuers, Quarterly Journal of Economics, 109, 625-658.

Bah, R. and Dumontier, P. (2001) R\&D Intensity and Corporate Financial Policy: Some International Evidence, Journal of Business Finance \& Accounting, 28, 671-692.

Barca, F. and Becht, M. (2002) The Control of Corporate Europe. Oxford: Oxford University Press.

Baysinger, B. D., Kosnik, R. D. and Turk, T. A. (1991) Effects of Board and Ownership Structure on Corporate R\&D Strategy, Academy of Management Journal, 34, 205-214.

Becht, M. and Mayer, C. (2002) Introduction to the control of corporate Europe. In F. Barca and M. Barca (eds) The Control of Corporate Europe. Oxford: Oxford University Press.

Beneito, P. (2003) Choosing Among Alternative Technological Strategies: An Empirical Analysis of Formal Sources of Innovation, Research Policy, 32, 693-713.

Bennedsen, M. and Wolfenzon, D. (2000) The Balance of Power in Closely Held Corporations, Journal of Financial Economics, 58, 113-139.

Billings, B. A., Musazi, B. G. N. and Moore, J. W. (2004) The Effects of Funding Source and Management Ownership on the Productivity of R\&D, $R$ \& D Management, 34, 281-294.

Carpenter, R. E. and Petersen, B. C. (2002) Capital Market Imperfections, High-Tech Investment, and New Equity Financing, Economic Journal, 122, 54-72.

Chiao, C. (2002) Relationship between Debt, R\&D and Physical Investment, Evidence from US Firm-level Data, Applied Financial Economics, 12, 105-121.

Chung, K., Wright, P. and Media, B. (2003) Corporate Governance and Market Valuation of Capital and R\&D Investments, Review of Financial Economics, 12, 161-172.

Cohen, W. M. and Levinthal, D. A. (1990) Absorptive Capacity: A New Perspective on Learning and Innovation, Administrative Science Quarterly, $35,128-152$.

Crespi-Cladera, R. and Garcia-Cestona, M. A. (2002) Ownership and control of Spanish listed firms. In F. Barca and M. Becht (eds) The Control of Corporate Europe. Oxford: Oxford University Press.

Demsetz, H. and Lehn, K. (1985) The Structure of Corporate Ownership: Causes and Consequences, Journal of Political Economy, 93, 11551177.

Devereux, M. and Schiantarelli, F. (1990) Investment, financial factors, and cash flow: evidence from UK panel data. In R. G. Hubbard (ed.) Asymmetric Information, Corporate Finance and Invest- 
ment. Chicago, IL: The University of Chicago Press.

Finkelstein, S. and Boyd, B. (1998) How Much Does the CEO Matter? The Role of Managerial Discretion in the Setting of CEO Compensation, Academy of Management Journal, 41, 179-199.

Francis, J. and Smith, A. (1995) Agency Costs and Innovation. Some Empirical Evidence. Journal of Accounting and Economics, 19, 383-409.

Galende, J. and De La Fuente, J. M. (2003) Internal Factors Determining a Firm's Innovative Behavior, Research Policy, 32, 715-736.

Galende, J. and Suarez-Gonzalez, I. (1999) A Resource-based Analysis of the Factors Determining a Firm's R\&D Activities, Research Policy, 28, 891-905.

Gompers, P. and Lerner, J. (2006) The Venture Capital Cycle. Cambridge, MA: MIT Press.

Graves, S. B. (1988) Institutional Ownership and Corporate R\&D in the Computer Industry, The Academy of Management Journal, 31(2), 417-428.

Grinblatt, M. and Titman, S. (1998) Financial Markets and Corporate Strategy. Boston, MA: Irwin/ McGraw Hill.

Gugler, K. (2003) Corporate Governance, Dividend Layout Policy, and the Interrelation Between Dividends, R\&D, and Capital Investment, Journal of Banking E Finance, 27, 1297-1321.

Hall, B. H. (1992) Investment and Research and Development at the Firm Level: Does the Resource of Financing Matter? NBER Working paper.

Hambrick, D. C. and Finkelstein, S. (1987) Managerial Discretion: A Bridge Between Polar Views of Organizational Outcomes. In L. L. Cummings and B. M. Staw (eds) Research in Organizational Behavior. Greenwich, CT: JAI Press.

Hill, C. W. and Snell, S. (1988) External Control, Corporate Strategy, and Firm Performance in Research-intensive Industries, Strategic Management Journal, 9, 577-590.

Hirschey, M. (1985) Market Structure and Market Value, Journal of Business, 58

Holderness, C. G. and Sheehan, D. P. (1988) The Role of Majority Shareholders in Publicly Held Corporations, Journal of Financial Economics, 20, 317-346.

Hoskisson, R. E., Johnson, R. A. and Hill, C. A. (1993) Managerial Incentives and Investment in R\&D in Large Multiproduct Firms, Organization Science, 4, 325-341.

Hoskisson, R. E., Hitt, M. A., Johnson, R. A. and Grossman, W. (2002) Conflicting Voices: The Effects of Institutional Ownership Heterogeneity and Internal Governance on Corporate Innovation Strategies, Academy of Management Journal, $45,697-716$

Hosono, K., Tomiyama, M. and Miyagawa, T. (2004) Corporate Governance and Research and Development: Evidence from Japan, Economics of Innovation and New Technologies, 13, 141-164.

Jaffe, A. B. (1986) Technological Opportunity and Spillovers of R\&D: Evidence from Firm's Patents, Profits and Market Value, American Economic Review, 76, 984-1001.

Jensen, M. C. and Meckling, W. (1976) Theory of the Firm: Managerial Behavior, Agency Costs, and
Ownership Structure, Journal of Financial Economics, 3, 305-360.

Jones, E. and Danbolt, J. (2003) R\&D Project Announcements and the Impact of Ownership Structure, Applied Economics Letters, 10, 933936.

Jose, M. L., Nichols, L. M. and Stevens, J. L. (1986) Contributions of Diversification, Promotion, and R\&D to the Value of Multiproduct Firms: A Tobin's q Approach, Financial Management Journal, 9, 41-58.

Kochhar, R. and David, P. (1996) Institutional Investors and Firm Innovation: A Test of Competing Hypothesis, Strategic Management Journal, 17, 73-84.

Kroszner, R. and Strahan, A. (2001) Bankers on Boards: Monitoring, Conflicts of Interests, and Lender Liability, Journal of Financial Economics, 62, 415-452.

La Porta, R., Shleifer, A., Vishny, R. W. and Lopezde-Silanes, F. (1998) Law and Finance, Journal of Political Economy, 106(6), 1113-1150.

La Porta, R., Lopez-De-Silanes, R. and Shleifer, A. (1999) Corporate Ownership Around the World, Journal of Finance, 54, 471-517.

La Porta, R., López-De-Silanes, F. and Zamarrita, G. (2003) Related Lending, Quarterly Journal of Economics, 118, 231-268

Le, S. A., Walters, B. and Kroll, M. (2006) The Moderating Effects of External Monitors on the Relationship between R\&D Spending and Firm Performance, Research Policy, 59, 278-287.

Lee, P. G. (2005) A Comparison of Ownership Structures and Innovations of US and Japanese Firms, Managerial and Decision Economics, 26, 39-50.

Lee, P. G. and O'Neil, H. M. (2003) Ownership Structures and R\&D Investments of US and Japanese Firms: Agency and Stewardship Perspectives, Academy of Management Journal, 46, 212-225.

Leech, D. and Manjon, M. C. (2002) Corporate Governance in Spain (with an Application of the Power Indices Approach), European Journal of Law and Economics, 13, 157-173.

Love, J. H., Ashcroft, B. and Dunlop, S. (1996) Corporate Structure, Ownership and the Likelihood of Innovation, Applied Economics, 28, 737-746.

Megginson, L. (2000) Corporate governance in publicly-quoted companies. In OECD (ed.) Corporate Governance of State-owned Enterprises in China. Beijing: OECD.

Miozzo, M. and Dewick, P. (2002) Building Competitive Advantage: Innovation and Corporate Governance in European Construction, Research Policy, 31, 989-1008.

Ortega-Argiles, R., Moreno, R. and Caralt, J. S. (2005) Ownership Structure and Innovation: Is There a Real Link? Annals of Regional Science, 39, 637-662.

Petersen, M. A. and Rajan, R. G. (1994) The Benefits of Lending Relationships: Evidence from Small Business Data, Journal of Finance, 49, 3-37.

Porter, M. E. (1990) The Competitive Advantage of Nations. New York: Free Press.

Porter, M. E. (1992) Capital Disadvantage: America's Failing Capital Investment System. Harvard Business Review, 70, 65-82. 
Rajan, R. G. and Zingales, L. (2003) Banks and Markets: the Changing Character of European Finance. NBER Working Paper Series.

Schaller, H. (1993) Asymmetric Information, Liquidity Constraints and Canadian Investment, Canadian Journal of Economics, 26, 552-574.

Tihanyi, L., Johnson, R. A., Hoskisson, R. E. and Hitt, M. A. (2003) Institutional Ownership Differences and International Diversification: The Effect of Board Directors and Technological Opportunity, Academy of Management Journal, 46, 195-211.

Tirole, J. (2001) Corporate Governance, Econometrica, 69, 1-35.

Tosi, H. L., Katz, J. P. and Gomez-Mejia, L. R. (1997) Disaggregating the Agency Contract: The Effects of Monitoring, Incentive Alignment, and Term in Office on Agent Decision Making, Academy of Management Journal, 40, 584-602.

Tylecote, A. and Ramirez, P. (2006) Corporate Governance and Innovation: The UK Compared with the US and "insider" economies, Research Policy, 35.

Von Thadden, E. L. (1995) Long-Term Contracts, Short-term Investment and Monitoring. Review of Economic Studies, 62, 555-575.

Wahal, S. and Mcconnell, J. J. (2000) Do Institutional Investors Exacerbate Managerial Myopia? Journal of Corporate Finance, 6, 307-329.

Yafeh, Y. and Yosha, O. (2003) Large Shareholders and Banks: Who Monitors and How? The Economic Journal, 113, 128-146.
Josep A. Tribo is an Associated Professor of Finance at the Department of Business Administration at the Universidad Carlos III de Madrid. He holds a PhD in Economics from Universitat Autònoma de Barcelona. His research interests centre on the financing of R\&D, contract design and corporate governance.

Pascual Berrone is an Assistant Professor at IESE Business School. He has held two visiting scholar appointments at Arizona State University in recent years. His current research interests focus on various aspects of the interface between corporate governance mechanisms and corporate social responsibility. His interests also include innovation and social issues and their impact on firms' overall performance.

Jordi Surroca is an Associated Professor of Management at the Department of Business Administration at the Universidad Carlos III de Madrid. He holds a PhD in Management from Universitat Autònoma de Barcelona. His research interests centre on stakeholder management, firm strategy, innovation and corporate governance. 
Copyright of Corporate Governance: An International Review is the property of Blackwell Publishing Limited and its content may not be copied or emailed to multiple sites or posted to a listserv without the copyright holder's express written permission. However, users may print, download, or email articles for individual use. 